\title{
TO STUDYSEED GERMINATION PERCENTAGE OFBRINJALBY USINGTRICHODERMASPECIES
}

\author{
P.S. Anarse* and I.G. Sayyad \\ Dept. of Botany, Gandhi College, Kada Dist Beed \\ *Corresponding Author: panduranganarse43@gmail.com
}

Communicated: 24.07.2020

Revision :29.07.20 \& 23.8.2020

Accepted: 02.09.2020

Published: 30.09.2020

\begin{abstract}
:
The Present investigation was carried out at kata on brinjal to determine the seed germination percentage of brinjal by using Trichoderma species. The efficiency of Bio-control means in controlling seed borne fungal diseases by using one Trichoderma species. Four different hybrid varieties of Brinjal and one wild varieties of Brinjal planted in pot for experimental work in Botany garden. The seed were purchased in various company i.e Ankur, Panchganga, Arnav. Mahyco and wild variety. The seed germination in Ankur is 70\%, Panchganga $80 \%$, Arnav 90\%, Mahyco 92\% germination were seen as compare to wild and control variety.
\end{abstract}

Key Words: - Seed germination, Trichoderma, Hybrid varieties, Brinjal

\section{INTRODUCTION:}

Brinjal (Solanum melongena L.) belongs to the family Solanaceae and is known under the botanical name. It is affected by several diseases, which do not control the plants to grow and yield to the best of genetic potential. Various disease management methods have been implemented to combat and eradicate pathogenic fungi. These include cultural, regulatory, physical, chemical and biological methods. In that situation Biocontrol offers a good choice to grows to control the disease avoid the pollution Biological control of plant disease is suggested as on alternative to chemical control (Cook, 1977) and is considered as a cost effective and an environmental ecofriendly technique. Humus an organic rich soil of valley is flavoured to flourish the bioagents easily can control the diseases. Infected omestic antagonistic are most virulent strains to the pathogens (Dohroo, 2001) because of their persistent capability under soil and local climate conditions.

\section{MATERAIL AND METHOD:}

The practical work is done in the laboratory as well as in pot culture in botanic garden three hybrid varieties of seed and one wild variety taken for the study of seed borne fungi on seed germination of Brinjal, Ankur, Panchganga, Mahyco, Arnav and wild variety of each of 100 seeds were sown in pot. The seed are treated with Trichoderma Species. The germination percentage of seed Mahyco is more than that of others. The seed health test is done by standard method (ISTA, 2001). The seed borne fungal pathogen associated with seeds was observed by binocular microscope by the key of Mathurand Kongsdal (1994). BAU- Biofungicide (Trichoderma based preparation Hossain (2011) was collected from diseases resistance laboratory.

The germination percentage of hybrid varieties is more than that of wild variety by using the Trichoderma speces to control the pathogen of diseases. The height of stem, length of leaf treated plants is large than of control plants. Thus, it is reported that least but similar prevalence of the fungi was recorded in the varieties tested.

\section{RESULT AND DISCUSSION:}

The effect of Trichoderma species on seed germination were studied by taking four different hybrid varieties and one control. The control have 
used as surface sterile by distil water. The seeds were soaked overnight in cultural filtrate and distil water (control). The seed germination in mahyco is highest than that of others. Highest impacts were seen on the seed germination of local or control variety. It was found that local and Ankur variety was seen to be more sensitive for Trichoderma.

The plant length improved with the increased in the dose of fungus bio control agents such as Trichoderma viride and Trichoderma harzianum. The plant height was observed in pot NO 1 with 2 gminoculums of bio control agents Trichoderma. viride and Trichoderma harzianum. It was followed by plants treated with $2.0 \mathrm{gm} 1.5 \mathrm{gm}$ and $1.0 \mathrm{gm}$ of inoculum as compared to untreated which shows lowest plant growth. Bhat, etal (2003), reported that bio control agent Trichoderma viride and Trichoderma harzianum to stimulate of brinjal plant as compaired to the uncontrol plants.

Effect of the fungi on germination of Brinjal seed of four hybrid verities presented in the table. Significantly the highest germination and growth rate was recorded more in Pot No. 1 as compared to other. This is due to the Bio control of Trichoderma. viride and Trichoderma harzianum.

\section{REFERENCES:}

Bhat; Z.A.; Bhat M.A. and Shawl; A.S. (2003) Comparative efficacy of biocontrol agents botanical extracts and fungicides in management of Chickpea wilt caused by Fusarium oxysporum f. sp. ciceri proceed National seminar on Recent Advances In Plant Science Research 1214 Oct -2003; pp45.

Cook, R.J. (1993) - ,Making greater use of introduced micro-organisms for biological control of plant pathogens, Annual Review of Phytopathology, 31:53-80.

Dohroo N. P. (2001) Study on population dynamics of naturally occurring Trichoderma harzianum Rifai and its antagonistic potential against rhizome rot of Ginger. Indian J. plant pathol ; 19 (1 \&2) : 39-43.

Hossain KS and Bashar MA (2011). In vitro effect of plant extracts, fungicides and antibiotics on the fungal isolates associated with damping-off disease of crucifers. Journal of Agro forestry and Environment. 5(2): 17-20.

ISTA - (International Seed Testing Association) (2001). International Rules for Seed Testing, Rules Amendments. Seed Sci. and Tech. 29 (2): 1-127.

Mathur S.B. and Konqsdal, O. (1994), Seed Mycology Description and Ilustration of Fungi DGISP for developing Denmark, Istedn.

Effect of Trichoderma virideon seed germination of Brinjal

\begin{tabular}{|l|c|c|c|}
\hline \multirow{2}{*}{ Variety } & \multirow{2}{*}{ Treatment } & \multicolumn{2}{c|}{ Germination \% after } \\
\cline { 3 - 4 } & & $\mathbf{1 0}$ days & 20 days \\
\hline Ankur & T. viride & $80.7 \%$ & $90 \%$ \\
\hline Panchganga & T. viride & $70.9 \%$ & $82 \%$ \\
\hline Arnav & T. viride & $70 \%$ & $70.7 \%$ \\
\hline Mahyco & $T$. viride & $75 \%$ & $92 \%$ \\
\hline Wild (control) & - & $40 \%$ & $42 \%$ \\
\hline
\end{tabular}

